\title{
Fiscal Adjustment: Trade-offs of Macro-economic Goals and Recent Policy Reforms in Pakistan
}

\author{
MushTAQ AHMAD
}

\section{INTRODUCTION}

Fiscal policy, being an embodiment of government measures to raise resources through taxes, tariffs of utilities, user charges and pricing of public sector goods, diverts resources from private sector to the government which rechannels these resource into socially preferred activities. The resource diversion and their rechannelisation helps achieve certain economic goals, and for this reason, the fiscal policy has strong interactive linkages with other macro economic policies. By virtue of this strong bond, the fiscal indicators have a close interactive association with other macro economic indicators. For this reason, the role of fiscal policy is inevitably vulnerable to influences of other economic policies and fiscal discipline and general economic health of the country become interlinked. This linkage results in generating trade offs between different macroeconomic policy goals.

The aim of this paper is to demonstrate how interaction of macro economic policies in Pakistan has moved over the years in past and to assess the ultimate impact on fiscal adjustment of economic policies initiated under the structural adjustment and stabilisation (SAAS) reforms. This presentation centres around the basic hypothesis that the fiscal stability chiefly depends on interaction between public finances and other macro indicators of the economy which are differently influenced by different policies. The objective is to demonstrate how conflicting goals made the task of the policy mix under SAAS reforms difficult in reducing the fiscal gap.

Mushtaq Ahmad is Member, National Tariff Commission, Islamabad.

Author's Note: I am grateful to Dr Sarfraz K. Qureshi for some useful suggestions towards refining this paper. 
The presentation in the paper has been ordered in four parts. The first part describes macro economic scenario, albeit briefly, prevailing at the turn of the 1980s, a time period when a departure from the old development strategy was conceived and a new agenda of structural reforms was put in place. This provides a background for the second part which presents a short account of the reforms launched since the close of the 80s. The third part provides an analysis of how the implementation of different policy reforms in different sectors has impacted on the public finances. The disaggregated analysis of the fiscal and non fiscal factors initiated by the reform programme of the government to put the economy back on a track of fiscal adjustment is also provided in this part. The concluding section explores alternative possibilities for forging improvements in the existing national development strategy so that it succeeds in achieving fiscal discipline while pursuing other goals.

\section{MACRO-ECONOMIC SITUATION IN 1980s}

During the first four decades since independence, different development strategies were pursued. By the end of that period, the performance of the economy in terms of growth, equity and stability is a mixed one. On the bright side, there was high and sustained economic growth of around 6 percent per annum. There was also marked diversification in the production edifice as the manufacturing sector grew from a negligible base to a substantial base. The tertiary sectors also grew in importance. The external sector considerably expanded. It had generated an appreciable growth in exportable surplus. To meet the country's growing requirements of capital and raw material, imports were financed by continued aid inflow and Pakistan's hard earned foreign exchange. These developments were accompanied by moderate expansion in social services and physical infrastructure like energy, electricity, telecommunications and roads. The dismal side of the story is that the economy remained persistently in fiscal and BoP deficits. These deficits primarily reflected the national resource gap: national savings hovered around 15 percent of GDP while investment was maintained at over 20 percent of GDP. Pursuing goal of high GDP growth could have pushed macro-economic stability into a jeopardy. Fiscal indiscipline had persisted, taxation had disappointedly settled at a low level of 14 percent of GDP while budgetary expenditure had continued to rise. Government's borrowing had reached an alarming level. Subsidies and debt servicing had pre-empted resources from the routine functions of the Government; the whole development budget was being financed for a long time through borrowing. Since the early 80s the government's non-inflationary resources fell short of current expenditure and as a result the deficit in the current budget was also met through borrowings.

Exports had for years in a row fell short of imports; and the current account of BoP had stubbornly remained in the red. The country's dependence on foreign borrowings had increased and even most of the borrowings were consumed for debt 
servicing, causing ultimately a steep fall in foreign aid inflow. Heavy recourse was made to borrowing from the banking system for meeting the budgetary requirement; this crowded out the private sector and in fact the monetary policy has rightly been criticised as having been made a hostage to the fiscal policy. Bank credit was rationed through annual credit plan, and it was over regulated. Interest rate for many activities was zero and in many cases negative in real terms. Social sectors considerably lagged behind the real sectors and the country has been ranked very low among other developing countries of the region when judged by social indicators like literacy rate, infant mortality, access to potable water, sanitation and housing facilities. Some sections of the society did not adequately benefit from the past growth. Research studies indicate some improvement in poverty incidence from 1979 to 1988 but the incidence of poverty has gone up in the 1990s. There was a large number of people living below poverty line. The growth had also engendered many disparities among the people in their access to education and social amenities. The disparities hit hard the rural masses, women and children. Unemployment has remained persistently a structural problem. The open unemployment, estimated by using broad definition of employment as taking a person employed who worked for one hour or longer in a week, was estimated at 5-6 percent and yet when adjusted for underemployment it could be no less than one fifth of the total labour force. Its incidence was high among the educated youth and the women. Demand-supply gap in physical infrastructure had widened; road network, telecommunication facilities, electricity etc. were assessed inadequate to support the existing 6 percent per annum in future.

The weaknesses and problems assessed in the late 80s could be capsuled as: (a) mismanagement of the economy displayed by persistent fiscal imbalance, heavy reliance on borrowings, low savings rate, structural deficit in balance of payments, domination of public sector in the economy, excessive regulatory system and continued inflation; (b) low productivity of the real sectors and inefficient production edifice; (c) high population growth and neglect of social sectors reflected in indicators like low literacy rate, high unemployment, skewed income distribution and high poverty incidence, inadequate health facilities, regional and gender disparities in sharing the benefits of growth; and (d) weak physical infrastructure, manifested into qualitative and quantitative inadequacies in transport and communication network, and sluggish growth in energy resources.

A diagnostic review of lopsided development over the first four decades helps in the identification of many a factors which the past policies have either failed to recognise or the policy-makers had consciously ignored them as these were considered to be incongruous to their vested interests. The other most probable reason, could also be that soft options, based on political grounds, were preferred over long term decisions, which initially appeared to be painful and politically tough, but would have ultimately steered the economy out of the difficulties and would have served the national interest. 


\section{SYNOPSIS OF RECENT REFORMS}

The government has adopted a comprehensive agenda of structural adjustment and stabilisation (SAAS) reforms to attend to structural problems and to put the economy back on the track of growth recovery with economic stability, a key element of which is the goal of improving fiscal discipline, mainly by reducing budgetary gap. [for details of reforms see Ahmad (1997), Economic Survey (199293) and Qureshi (1995)]. To maintain a cohesion in discussion, the synopsis of reforms is presented under four groups by virtue of the ultimate goals these reforms are envisaged to achieve. First, on top of the agenda was (and is still) the goal of Macroeconomic Stability consisting of three ingredients of budgetary balance, BoP improvement and reduction in inflation. Fiscal and monetary policy reforms and devaluation have been mainly aimed to achieve this. Second, the goal of promoting efficiency and fostering growth was intended to be achieved through deregulations and decontrols, privatisation, market liberalisation, institutional reforms and improvement in public sector efficiency. Third, the goal of Human Resource Development is to be attained through population control, improvement in social services, reduction in personal and regional disparities in access to social services and strengthening the social safety-nets. Fourth, the goal of expansion in physical infrastructure and development of energy resources was to be achieved through improved pricing system and encouraging the private sector, especially the foreign investors. We have selected those policies which had directly or indirectly impacted on public finances although these have been primarily targeted at some other specific goals.

\section{IMPLEMENTATION OF SELECTED POLICY REFORMS}

\section{Monetary Policy's Fallout for Public Finances}

Monetary Policy has been used as a supportive plank for the fiscal policy for a fairly long time in Pakistan. The central bank which is its executing agency, as is the case elsewhere in the world, was kept until recently as an appendix to Ministry of Finance. The monetary policy was excessively regulated and was used to provide support to fiscal policies. Interest rates were arbitrarily fixed by the central bank under the direction of the Government. Distorted structure of interest rates was pursued to favour lending to government for financing budgetary gap and meeting requirements of certain priority sectors like small farmers, locally manufactured machinery and some specified exports. General lending to the private sector was made at a high interest rate. (See Annex Tables 1, 2 and 3). In fact there was a wide dispersion in interest rate starting from minimum zero to a maximum of 9-10 percent and over time the cap on the maximum rate has undergone changes. The general lending rate for a considerably long time remained below the prevailing inflation 
rate, implying that real interest rate was negative. The bank credit to the Government for financing budgetary requirements was advanced at a very low rate; even most of the credit was at around one percent and besides that, the Government had a direct access to the surplus deposits of some public sector agencies at a low rate, though higher than one percent, and yet certainly much less than the inflation rate. The average inflation rate in the country has been around 7 percent per annum in the first four decades. The low nominal interest rate adjusted for inflation assured negative real interest rate on government borrowing from the banking system and thus the government borrowing from the banking system was substantially subsidised.

The central bank has been regulating bank credit through annual credit plans, implying direct control on total money supply as well as on its further allocation to different sectors of the economy. Monetary policy management was more or less on the pattern of centrally planned economies. The credit plan first reserved the credit for the government and the residual in the total annual credit ceiling was allowed to the private sector. The Government requirements for credit were essentially to meet budgetary gap and to finance commodity operations: the interest on the latter was higher than that on the former but that too enjoyed a concessional margin of 2-3 percent point over the general interest rate. They carried high weight in the annual credit plan as could be seen from the figures given below for selected years. (Table 1.)

Table 1

Government Access to Bank Credit

\begin{tabular}{|c|c|c|c|c|c|c|c|c|}
\hline \multirow[b]{2}{*}{ Years Sector } & \multicolumn{2}{|c|}{$1974-75$} & \multicolumn{2}{|c|}{$1982-83$} & \multicolumn{2}{|c|}{$1992-93$} & \multicolumn{2}{|c|}{ 1997-98 } \\
\hline & $\begin{array}{c}\text { Annual } \\
\text { Addition }\end{array}$ & $\begin{array}{c}\text { Cumulative } \\
\text { Stock }\end{array}$ & $\begin{array}{c}\text { Annual } \\
\text { Addition }\end{array}$ & $\begin{array}{c}\text { Cumulative } \\
\text { Stock }\end{array}$ & $\begin{array}{c}\text { Annual } \\
\text { Addition }\end{array}$ & $\begin{array}{l}\text { Cumulative } \\
\text { Stock }\end{array}$ & $\begin{array}{c}\text { Annual } \\
\text { Addition }\end{array}$ & $\begin{array}{c}\text { Cumulative } \\
\text { Stock }\end{array}$ \\
\hline Government Sector & 3.06 & 17.50 & 9.20 & 71.37 & 78.94 & 359.76 & 57.63 & 653.49 \\
\hline - Budgetary Financing & 1.52 & 13.83 & 5.63 & 55.44 & 65.70 & 322.77 & 48.46 & 554.98 \\
\hline - Commodity Operations & 1.54 & 3.67 & 3.57 & 15.93 & 7.34 & 30.20 & 10.59 & 63.66 \\
\hline Total Domestic Credit & 5.07 & 33.07 & 29.52 & 146.03 & 89.82 & 595.39 & 149.11 & 1202.35 \\
\hline
\end{tabular}

Within the country, the government taps three types of borrowings i.e. permanent debt, floating debt and unfunded debt. Of these the floating debt is the one obtained from the banking system as mentioned above. The other two categories of debt have been raised from the open market, the chief source of which is general public, but occasionally public sector financial institutions were also allowed to purchase government bonds and securities. Since the direct government borrowings from the central bank i.e. floating debt was done at a low nominal interest rate and such loans had a large element of subsidy. The government made frequently heavy reliance on this type of borrowing for meeting the budgetary gap. Until the early 80s floating debt was less than half of the total government debt. Government reliance on this source of borrowing starting tapering off in subsequent period in the 80s but its 
share had declined to the lowest level in 1991-92. As the process of the implementation of reforms continued the Central bank started gradually shifting from this source of borrowing to the open market operations. The Treasury bills and Government securities issued to borrow from the banking institutions were progressively auctioned in the market and the government has started offering a competitive interest rate in the open market. This interest rate has remained in the vicinity of 14-15 percent. These rates showed not only substantial increase over the nominal interest rates charged in the pre-reforms period but the real interest rates also turned out to be positive as the nominal rate exceeded inflation rate. Reforms had progressively exposed the government borrowing from the banking system to the open market forces. As a result the two developments of far reaching fiscal consequences have taken place. First, the government was, in a large measure, deprived of real subsidy on borrowing from the banking system and government had now to pay much higher nominal interest rate, making on the other hand real interest rate positive. Second, raising resources through open market operations by the government, created a competition with the private sector and as a result the general level of interest rates in the country went up and this also pulled up the cost of borrowings in the form of permanent debt and unfunded debt. This situation caused a double pressure on debt liability and consequently the overall cost of government borrowing shot up and the debt servicing liability also increased. This has had a snow ball effect on the internal outstanding debt profile. The share of debt servicing in the current budget has substantially increased. The debt servicing coupled with defence alone eat up most of the government revenue. The government is now in a debt trap; it has to borrow not only to meet the primary fiscal deficit but also to service its past loans. How the debt trap has emerged over time could be gauged from the trends in the selected debt related indicators given in Table 2.

Table 2

Outstanding Domestic Debt

(Rs Billion)

\begin{tabular}{lcrrr}
\hline $\begin{array}{l}\text { Years Debt-related } \\
\quad \text { Indicators }\end{array}$ & $1980-81$ & $1985-86$ & $1992-93$ & $1997-98$ \\
\hline Total Domestic Outstanding & 58.09 & 203.12 & 615.31 & 1279.75 \\
Debt (\% of GDP) & $(20.9)$ & $(39.5)$ & $(45.9)$ & $(42.1)$ \\
- Floating Debt & 31.69 & 57.63 & 215.82 & 549.71 \\
- Permanent Debt & 13.76 & 58.23 & 245.49 & 265.69 \\
- Unfunded Debt Adjusted & 12.64 & 57.63 & 154.00 & 464.35 \\
$\quad$ for Debt Servicing & & & & \\
$\quad \begin{array}{l}\text { Interest Payment on Floating } \\
\text { and Permanent Debt }\end{array}$ & $4.70^{1}$ & 19.02 & 62.73 & 164.52 \\
$\quad \begin{array}{l}\text { Note: The figure has been extracted from a long series of data. } \\
\end{array}$
\end{tabular}


Repayment of principal in the case of all types of loans is adjusted against new loans each year but interest payment is adjusted only against unfunded loans. Thus debt servicing shown in the budget documents includes only interest payments for floating and permanent debts while it is repayment of principal and interest in the case of foreign loans. As the government has moved away from cheaper source of credit borrowing from the banking system, the growth of interest payments, on domestic debt has accelerated and outpaced the other components of debt servicing. (See Table 3).

Table 3

Debt Servicing as \% of GDP

\begin{tabular}{lcccc}
\hline & $1979-80$ & $1985-86$ & $1992-93$ & $1997-98$ \\
\hline Interest Payment on Domestic Debt & 1.1 & 2.5 & 4.7 & 5.6 \\
Interest Payment on Foreign Debt & 1.0 & 1.2 & 1.3 & 1.0 \\
Repayment of Principal on Foreign Debt & 2.4 & 2.1 & 2.2 & 3.2 \\
Total Debt Servicing & 4.5 & 5.9 & 8.3 & 10.1 \\
\hline
\end{tabular}

\section{Fiscal Implications of External Trade Policy Reforms}

Pakistan has a long history of excessively regulated foreign trade regime. The foreign trade has been considered a main source of revenues and the trade, particularly imports, was subject to high tariffs, which had simultaneously provided protection to the local industry. The tariff structure maintained wide dispersion of rates accompanied by enormous exemptions. Duty drawbacks and export rebates were allowed for promoting certain exports and some exports related industries. Besides tariffs, quantitative restrictions were also used to discourage some imports as well as exports: thereby checking imports was to shelter some local industries while restricting exports was considered necessary to maintain adequate domestic availability of some commodities at low prices to the consumers. Pakistan has all along been dependent on foreign capital inflow to meet domestic resource gap, and this has provided leverage to donors to exert pressure in influencing the direction of the development strategy of the country. They have never been happy with regulated trade regime but in the 80s, donors, IMF and World Bank have largely succeeded in convincing the authorities in Pakistan to negotiate an agenda of reforms for trade liberalisation. Since then the country has been steadily progressing in reducing the tariff and non tariff barriers. The agenda of reduction in non tariff barriers has been speedily completed but the tariff reforms were interruptedly implemented. The punctuation in implementing the tariff reforms was necessitated purely on the ground of revenue loss, albeit there was wide spread agitation from local industry. Nevertheless the pace of trade reforms has been quite encouraging since 1988-89. 
In March 1997, the largest step taken for reducing protection related to slashing the maximum tariff rate to 45 percent from 65 percent and minimising the multiple tariff rates to only 4 with cascadence on the basis of value addition, implying maximum rate on the import of the finished goods while minimum on the imports of raw material and machinery used in the high value added local industry but not locally manufactured. The ultimate goal of the reforms is to bring maximum tariff rate to 35 percent as agreed by way of conditionalities with IMF (which coordinates on this with World Bank, ADB and Pakistan Economic Forum, a successor of Aid to Pakistan Consortium) and also as a requirement of WTO Charter already signed by Pakistan. The existing situation characterised by only 45 percent maximum tariff with four tariff rates, completely eliminated all non tariff barriers, only a few items on the negative/restricted lists (and that too on very genuine grounds of security, religion etc.) demonstrates great efforts on the part of the government to move the economy towards liberalisation as especially contrasted with the situation prevailing ten years ago, when in 1987-88 there existed a huge negative and restricted list of items, maximum tariff rate was as high as 225 percent, coupled with 5 percent import surcharge, 5 percent Iqra surcharge and 4 percent licence fee, super imposed with an institutional cap in the form of Office of the Chief Controller, Imports and Exports to issue licences. Sequenced removal of restrictions on foreign trade over time could be seen in Annex Table 4. In the process of liberalisation, there has also been marked progress in removing certain exemptions and improving the system of duty draw backs.

The ultimate aim of liberalisation was not only to improve efficiency of the local industries by exposing them to international competition (in fact this stipulated gradual elimination of inefficient industries which have grown under high protection and promoting efficient industries which could expectedly cope with the changing global system) and it was also meant to integrate the economy into global economy. By removing distortions the authorities contemplated that the economy can grow on its intrinsic strength and find its place in the global economy on the basis of comparative advantages in trade and production.

During the last ten years while there was good progress on the front of implementation of reforms the balance of trade had remained under continued pressure. The reforms have exerted both direct and indirect adverse effects on the public finances of the country. At the start of the reforms the custom duties stood the largest source of government revenues and that claimed 40.7 percent of total tax revenues in 1987-88 and their share has declined to 21.7 percent in 1997-98. Now only imports fetch revenues while the exports which also used to fetch handsome revenues earlier to the government are now totally exempted from tariffs. The effective import duty has declined from 33.8 percent to 18.0 percent over this period. The indirect effect of trade reforms is that some local industries which were running under protection have heavily suffered and some of them have come to a standstill 
and the recessionary growth trends in manufacturing sector, even negative in recent years, has reduced revenue potentials to be tapped through sales tax and excise duty. This provides a glaring unfavourable contrast with the period immediately preceding the launching of reforms when manufacturing growth was around 8 percent per annum.

\section{Budgetary Impact of Foreign Exchange Policy Reforms}

Under the exchange rate system prior to 7th January 1982, Pak Rupee was linked with the US dollar and infact the fixed exchange rate system continued since 1947 although the Rupee had been devalued on two occasions till 7th January, 1982. Since the new exchange rate policy brought about a switch over from fixed parity with US dollar to a managed floating system under which the Rupee was linked with a basket of currencies of country's major trade partners. The Rupee had remained subjected to periodic depreciation/devaluation. During January 1982 to 1987 the Rupee was devalued by 43 percent and under the current exchange reforms the Rupee came under great pressure and there was persistent pressure by the donors for devaluation. There were also a genuine ground because the domestic prices recorded higher increases over the preceding period and higher inflation, therefore, justified correction in the exchange rate through devaluation with a view to protect competitiveness of exports in international market.

During the period, 1987-88 to 1997-98, the Rupee recorded against the US dollar a depreciation/devaluation of 59 percent. The rupee: dollar parity changed from Rs 17.6/dollar to Rs 43.2/dollar. This directly impacted the Rupee debt servicing liability in the case of foreign debt. As demonstrated in an earlier table, repayment of foreign debt as percent of GDP has gone up from 2 percent of GDP in 1987-89 to 4 percent of GDP in 1997-98 and is estimated at 4.1 percent of GDP in 1998-99. The repayments/amortisation of foreign debt stood at Rs 13.5 billion in 1987-88. The positive impact of devaluation expected to come through higher rupee value of imports leading to higher yield of advalorem import duties was neutralised by negative impact of falling imports and scaling down of tariffs. The exchange rate policy reforms pushed the expenditure to rise more in the process of reforms than in the earlier period. The Rupee valued debt servicing of foreign loans has directly increased and thus built pressure on government budget.

\section{Privatising and Divesting Policies' Impact on Budget}

The tradition of direct involvement of the public sector in economic activities started in the early history of the country when the government established Industrial Development Corporation of Pakistan to undertake industrial projects. In fact that was necessitated due to the fact that the private sector was shy to undertake capital intensive industries because that did not have the experience and expertise in the field. Nevertheless these projects were ultimately to be sold to the private sector on 
completion. However a radical change occurred in the national economic philosophy in the 70s, and an equity-oriented development strategy was pursued under which large scale nationalisation took place in the fields of major industries, banking, insurance, shipping and trade. As a result public corporate sector emerged in tandem with general government and that started maintaining its own parallel budget. There was a fiscal linkage between the general government and the public corporate sector. The pricing policies were controlled by the government which kept prices below cost and consequently the public sector enterprises were meeting their deficit by borrowing funds from central government, banking sector and private sector but in certain cases the Federal Government gave subsidy on some operations undertaken under specific government directives.

The public corporate sector as a whole has remained for a long time in net deficit and such persistent deficit has pushed it into a debt trap. This has thus created problems for monetary and fiscal policies. The fixed investment in the corporate sector was mostly owned by the government and its profitability soon turned into loss which had direct bearing on the public finances. Under the reforms around the turn of the 80s the government has off loaded a big chunk of the public corporate sector and so far 105 units falling in manufacturing, banking, PTC vouchers, and power sectors have been divested against Rs 60.67 billion and an amount of Rs 57.23 billion plus mark up of Rs 1288.3 million has been received. Of this an amount Rs. 37.66 billion has been used by Government/ WAPDA during 1994-95 to 1997-98 in routine operations and about Rs 5 billion has been used for retirement of public debt.

\section{Administered Pricing Policy}

The prices of agricultural inputs, gas and public utilities were controlled by the Government and these were invariably kept below their actual cost. In most cases the public sector was directly involved in the production and distribution of these commodities and utilities, and the price-cost differential was met either by way of subsidies or through borrowings. Maintaining such differential persistently over a long period caused the debt liability of some public sector agencies like WAPDA and KESC to skyrocket. Under the price reforms the subsidies on agricultural inputs like fertiliser and pesticides has been almost eliminated and there has been some increase in the prices of agricultural non traded inputs like irrigation water, credit and electricity but even the revised prices did not cover total cost. Some progress has been made in implementing economic pricing but still sale prices of electricity and gas are much less than the cost which also continued to increase due to rising wages, rents and interests. The subsidy bill on fertilisers has sharply declined from Rs 1.4 billion in 1990-91 to Rs. 47 million in 1995-96 and was then completely eliminated in subsequent years. In the recent years only in 1994-95 and 1995-96 a subsidy of Rs 1 billion per annum was given on agricultural loans. 
These reforms have two positive effects: one is a clear move in the direction of reduction in the burden of subsidies on budget and the second is that economic pricing policy has been recognised as a cardinal principle of the national development strategy for achieving fiscal discipline.

\section{Budgetary Implications of Social Safety Net and Provision of Social Services}

In the process of reforms two important developments took place. First, it was recognised that in the transition phase of reforms income disparities at personal as well as regional (rural viz. urban) level have widened and poverty incidence risen. This was to be mitigated by having adequate social safety-net. In recognition of the need for improving the quality and coverage of social services like education, health etc. for upgrading low ranked human development indicators, the government had to increase social spending. The government had to subsidise wheat distribution network. Its budgetary impact has earlier declined from Rs 5.9 billion in 1991-92 to Rs 2.9 billion but has subsequently increased to Rs 11.7 billion in 1997-98. To assist the poor financially the government has to run Bait-ul Mal which entailed an endowment of Rs 2 billion. In February 1997 Poverty Alleviation Fund has been established with a Government-contributed endowment of Rs 2 billion. Loans of SBFC and HBFC are also subsidised. Expenditure on education and health sectors has been increased in parallel to overall expenditure under budget but a gigantic SAP stipulates huge expenditure which has put a heavy impact on the budget.

\section{Direct Role of Fiscal Policy Reforms}

The focus of the fiscal policy reforms was on reduction in fiscal deficit by mobilising more revenues and curtailing public expenditure. The measures aimed at mobilising additional resources envisaged fundamental changes in the taxation system in the form of shifting emphasis from the taxes on foreign trade to generalised income and consumption taxes, broadening tax base, reducing tax rate, curtailing numbers of tax slabs, switching over from quantum to advalorem basis in the case of taxes on foreign trade, excise duty and sales tax. In the case of taxes on international trade sharp reduction has been made in the maximum tariff which has been brought down to 45 percent and their structure is simplified to only four cascadence tax rates. The coverage of excise duty and sales tax has also been increased and their structure has been reformed in terms of reduction in the number of tax slabs and switch over from quantum to advalorem basis. Direct taxes have also undergone similar reforms as the tax rates has been reduced and many services and agriculture have been brought into their tax net.

Government has succeeded in curtailing the level of public development expenditure in relation to GDP and in current expenditure some selected expenditure categories like transfer payments particularly subsidies have been reduced. 
Nevertheless the propensity to reduce the current expenditure is limited as most of the items like interest payments and expenditure on essential services like law and order, general administration cannot be reduced beyond a certain level. Moreover with a time lag, the expenditure on projects and economic activities undertaken under development programmes are shifted, on their completion, to the current expenditure and this is a continuous inflow into the current expenditure. Notwithstanding the inflexibility in the current expenditure, the reduction in public expenditure had become possible through reduction in the development expenditure. The reforms did not show satisfactory results in tax realisation and in fact the tax receipts pace has rather slackened. In the second half of the 80s the tax revenues were on average slightly higher than 14 percent of GDP while this average has slightly slipped to little over 13 percent. The non tax revenues had shown a slight improvement in the early 90s as these were on average 4.3 percent of GDP but these declined to less than 3 percent of GDP in the last three years through 1997-98. The overall expenditure had touched a peak at 26.7 percent of GDP in 1997-98 but in subsequent years the level started tapering off and it has declined to 21.8 percent of GDP in 1997-98. Relatively some decline has been recorded in both current and development expenditures but as already mentioned the development expenditure became the main victim of this reduction [See Annex Table 5].

Many fiscal specific factors have stood in the way of efficient implementation of fiscal reforms. The provincial government and local bodies did not actively participate in resource mobilisation and have thus failed to meet the mandate of the National Finance Commission awards which reflect the plan for intergovernmental fiscal relations. The other principal factors include a continued exclusion of potential tax handles, large scale tax evasion, anomalies in tariff policies, heavy tilt towards indirect taxes (inspite the reforms), lags in tax policy, lack of documentation, vague language of tax amendment rules, thriving black economy, and lack of compatibility of the taxation system with the requirements of the ensuing regional blocks and international trade system. Tightening the taxation system led to an under-invoicing of imports and over-invoicing of exports which is also feared to have caused capital flight [Commerce Minister's Speech (1998)]. Frequent changes in the taxation policy and allowing a large number of tax exemptions on one or the pretext have further compounded the fiscal problem.

\section{Secondary Effect of Reforms on Public Finances}

Reduction in the relative size of annual development programme in the budget made growth oriented projects, like those on water logging and anti salinity to starve. Dismantling protection tariff wall took a heavy toll on many industries. Withdrawal of subsidies on agricultural inputs inflicted heavy below to agriculture. As a result the growth of real sectors suffered in the 90s. Secondly under the reforms despite the government started tightening of the tax administration, tax evasion increased. 
Frequent devaluations prompted resort to foreign currency business which is mostly out of tax net. Similarly under-invoicing of imports became attractive. As a result under ground or black economy has considerably expanded. A recent research study has found that its annual growth has increased from 14 percent in the 80 s to 26 percent in the 90s [Iqbal et al. (1998)]. This trend combined with the depressed GDP growth has inhibited the pace of resource mobilisation under the existing taxation system.

\section{CONCLUDING REMARKS}

The experience of almost 10 years of implementing SAAS reforms reveals that non-fiscal policies have mostly conflicted with fiscal policy in achieving fiscal discipline. At the cost of painful tradeoffs the fiscal policy deficit has come down from 7 percent of GDP in the 80s to 5.4 percent of GDP in 1997-98. This reduction in fiscal deficit seems to have slowed pinched the growth tempo which in turn has reduced the revenue potentials [See Annex Table 5]. Whether the partial success of the reforms in limited areas outweighs the loss in the growth momentum is debatable. Certainly reduction in fiscal deficit does not fully explain the fiscal discipline because that could be a necessary condition but not a sufficient condition for fiscal discipline. Some what subdued deficit is accompanied with mounting debt liability, sluggish resource mobilisation and stubborn current expenditure place the public finances far away from the planned fiscal discipline.

In fact the agenda of SAAS reforms was too big to be efficiently managed when the country did not have the expertise to steer it through the vast restructuring of the economy. The basic principle of economics that economic policies option conflict in their goals has been over looked. The authorities have not been allowed sufficient time to appraise the reforms before these came under implementation because the donors pressed them to accept these as conditionalities for loans which were badly needed to cover the resource gap. Secondly the public, particularly business community, industry, and farmers have not been taken into confidence in formulating SAAS reforms. The press has always been hostile to them. The reforms were not debated at national forums, and thus no consensus was developed on the context of reforms. In short, the reforms got poor receptivity within the country.

The reforms lacked proper sequencing in their implementation. Monetary policy reforms were front loaded with adverse fiscal fall out. Similarly by effecting reduction in tariffs on foreign trade before ensuring compensatory domestic taxes was ill timed.

Absorption capacity was reduced by launching tight monetary and fiscal policy but that adversely affected domestic production. Moreover these policies failed to give support to stabilise the Rupee exchange rate. Excepting temporary slow down in 1997-98 the domestic prices remained under persistent pressure, keeping inflation in double digit. This distorted other policy objectives as well. 
Defaulted and non performing bank loans have totalled about Rs 184 billion by 31st March, 1998 (reported by Finance Minister to the National Assembly on 26th August, 1998-Business Recorder, 26th August, 1998) but their recovery is slow. This is the greatest hurdle in reforming the banking system. Lack of political will is considered a main cause of this malaise.

There is urgent need for corrections both in the policy mix and their sequencing. Consensus both at public and political level has to be developed on the reforms. A strong team at technical level in all relevant fields has to be put together so that a meaningful dialogue could be made on conditionalities with the donors. Legal framework for implementation of the reforms should be speedily developed. Taxation system should contain minimum exemptions and concessions which often cause tax leakages. Tax/tariff collection and administration needs to be strengthened and to be made immune to political influences. In no case, fiscal policy should be anti-growth. With a view to accelerate resource mobilisation as wall as to check fiscal leakage, fiscal devolution needs to be fostered. Transparency should be encouraged in revenue collections and public spending to avoid corruption and to minimise tax evasion.

The existing situation provides sound ground to conclude that the progress in reducing the deficit is not yet deeply entrenched in the economic structure and the fundamentals to support its continued downward trend in the long run are still fragile. Continued effort on the part of the authorities with support of the public is required to strengthen the process of reforms on lines indicated in the previous analysis. 
Appendix Table 1 
Appendix Table 2 
Appendix Table 3 
Appendix Table 4 
Appendix Table 5 


\section{REFERENCES}

Ahmad, Mushtaq (1993) Taxation Policy in Pakistan: Grey Areas and Need for Reforms. Paper presented at seminar organised by the Pakistan Economic Forum, 20-21 February.

Ahmad, Mushtaq (1997) Experience of Developing Countries in Growth, Price Stability and Income Distribution. Presented at PIDE's Course, 28-29th August.

Commerce Minister of Pakistan (1998) Various Policy Statements/Speeches Made in September to December.

Pakistan, Government of (1992-93) Economic Survey of Pakistan, 1992-93. Islamabad: Ministry of Finance.

Pakistan, Government of (n.d.) CBR Year Book 1995-96. Islamabad.

Iqbal, Zafar et al. (1998) The Underground Economy and Tax Evasion in Pakistan: A Fresh Assessment. Pakistan Institute of Development Economics, Islamabad. (Research Report No.159.)

State Bank of Pakistan (1998) Statistical Bulletins of Selected Months. Karachi. State Bank of Pakistan (Various Issues) Annual Report of Selected Years. Karachi. 